Research Article

Hernán Pas*

\title{
From the Newspaper Serial to the Novel (1853-1863): Mediation of the Periodical Press in the Foundation of Alberto Blest Gana's Narrative Project
}

https://doi.org/10.1515/culture-2021-0005

received October 15, 2020; accepted January 28, 2021

\begin{abstract}
Scholarly studies on Alberto Blest Gana have generally disregarded the author's production prior to his narrative cycle, begun with his novel La aritmética en el amor [Arithmetic in Love] (1860), awarded first prize in a literary contest sponsored by the Universidad de Chile. Nonetheless, the canonical cycle of his first narrative period (which includes his famous Martín Rivas and El ideal de un calavera) shares with his earlier fiction the fact that the novels were originally published in the press. Indeed, with the exception of the award-winning novel and Juan de Aria - published in the Aguinaldo of the newspaper El Ferrocarril - all the author's production from his first narrative period was published in periodical publications, decisive in consolidating his narrative project. This essay analyses the mediation of the periodical press (and its subgenres, such as the folletin [newspaper serial] and the artículo de costumbres [a literary vignette of customs]) in the foundation of Blest Gana's narrative scheme, contemplating the diversity of his production. The main features of his project were embodied, materially speaking, in the space of the folletin. It was in this space, in short, where the author's narrative managed to challenge an extended reading public, necessary for the constitution of a national literature.
\end{abstract}

Keywords: periodical press, serial fiction, epistolary genre, costumbrismo, Blest Gana

\section{Introduction}

Critics generally agree that, in the mid-1860s in Chile, "the progress of national literature had already acquired a life of its own," ${ }^{1}$ as José Victorino Lastarria has so concisely stated in his Recuerdos literarios (423). The expansion of the print market, the increase in periodicals and a middle class or urban reading public - resulting in part from a progressive development of formal education, which by that date had raised Chilean literacy rates to $17 \%$ - undoubtedly favoured the consolidation of the literary programmes drawn up and discussed by the Sociedad Literaria of $1842 .{ }^{2}$ In the 1950s, as Bernardo Subercaseaux maintains (175), literature came to have the same importance as history had in the previous decade. But it was no

1 Translation mine. All translations from Spanish to English are mine unless otherwise indicated. Quotations of Blest Gana are given in Spanish and English. In other instances, quotations are in English only, with rare exceptions where Spanish and English are necessary for clarity.

2 Data on literacy refer to the year 1865. Cfr. Serrano (99).

* Corresponding author: Hernán Pas, UNLP-IdIHCS-CONICET, La Plata, Buenos Aires, Argentina, e-mail: hpas@fahce.unlp. edu.ar 
longer focused on society's regeneration and emancipation. Rather, literature began to respond to aesthetic demands and those of nationality.

These exigencies were channelled through a progressive increase in periodicals that dominated the print market and the main reading circuits. To be sure, periodicals were capturing and mediating the diverse interests of an emerging reading public whose dynamics created an incipient market for socialisation and democratisation in the reading practices of the time. La Gaceta del Comercio, El Progreso, El Semanario de Santiago, El Crepúsculo, and El Siglo, which in the 1840s, were joined by others, such as El Mosaico, El Alegre, or La Revista de Santiago. And a decade later, others emerged, such as El Correo Literario, the Revista del Pacífico, La Semana, and La Voz de Chile. ${ }^{3}$

In his annotated bibliography on Alberto Blest Gana (1830-1920), Jorge Román-Lagunas observed that almost all his scholarship has focused on no more than 5 of the Chilean author's 17 novels. Any of his work prior to La aritmética en el amor, therefore, has been considered to be the product of rather tentative beginnings or even the outlines for future novels (607).

Perhaps as a corollary to the opinions by the novelist himself, the critics have oriented their analysis, first, to the novelistic trilogy of this first narrative period, which began with La aritmética en el amorawarded and consecrated by the Universidad de Chile - continued with Martín Rivas (1862) and completed with El ideal de un calavera [Ideal of a Rogue] (1863); and, second, to the production of his final period, especially with the novels Durante la Reconquista [During the Reconquest] (1897) and El loco Estero [Crazy Estero] (1909). ${ }^{4}$

Nonetheless, if we examine some of his fiction prior to his award-winning novel, such as La fascinación [The Fascination] (1858), El primer amor [First Love] (1858), Un drama en el campo [A Drama in the Countryside] (1859), and even his first novel, Una escena social [A Social Scene] (1853), we can ascertain in them not only a preparatory exercise but also early traces of Blest Gana's eventual literary prose, along with signs of the author's most characteristic and eminent narrative topics, that is, what will become a Blestganian prose. By way of illustration, these works foreground the relationship between sentimental order and material interests (expressly, between love and money) which defines most of Blest Gana's protagonists in consonance with contemporary apologies for bourgeois morality such as that of Samuel Smiles. The epitome of this is undoubtedly Martín Rivas. Literary representation through figurations of female culture also features prominently. These early pieces also provide outlines of the author's most outstanding strategies of literary representation: these include epistolary communication; the pairing of opposite characters; the representation of characteristic social strata, notably, bourgeoisie and medio pelo; the thematisation of female education through reading; and inquiries on the spaces of domestic sociability.

In what follows, I will try to account for the feedback that takes place between the press and a narrative that is so-called Blestganian. In particular, I am concerned with the by-product of the folletin and three related issues: the costumbrista stamp [the depiction of customs, manners, etc.], the use of the epistolary genre, and the realist nature of the author's narratives. This inquiry will begin at the point of arrival, specifically reviewing the moment of consecration of the author's literary proposition with the awarding of La aritmética en el amor. This will be followed by an analysis of the functions of the epistolary genre within the context of Blest Gana's costumbrista narrative. Finally, I will end with a reading of Martín Rivas, a long saga constructed of stories published in the press before they reached their final destination in bookish format.

3 See works cited for the research date range of each newspaper consulted.

4 In a letter written on $7^{t}$ December 1863 to José Antonio Donoso, Blest Gana wrote: “Tú sabes, o te lo diré por si lo ignoras, que desde que escribí La aritmética en el amor, es decir, desde que escribí la primera novela a la que yo doy el carácter de literatura chilena, he tenido por principio copiar los accidentes de la vida en cuanto el arte lo permite" [You know, or I will tell you just in case you ignore this, that ever since I wrote La aritmética en el amor; that is, since I wrote the first novel which I consider to possess the characteristics of Chilean literature, I have made it a principle to copy the accidents of life as far as art will allow it] (Fernández Larraín 51). 


\section{The Triumph of La aritmética en el amor}

If we consider the marriage between periodicals, literary projects, and reading habits, 1859 is a key year. On 21 May 1859, the brothers Justo and Domingo Arteaga Alemparte launched La Semana. Revista noticiosa, literaria y científica. In its fourth issue, Alberto Blest Gana presented his short essay "De los trabajos literarios en Chile" [On Literary Works in Chile], where he reviewed the pitfalls and challenges of writers including himself - who advocated for the production of a national literature. In August, Lastarria founded the Círculo de Amigos de las Letras - to which he self-interestedly referred to in Recuerdos literarios - and Jacinto Chacón created in Valparaíso the Sociedad de Amigos de la Ilustración; both associations disseminated information through La Semana and La Revista del Pacífico. ${ }^{5}$

Additionally, this was also the year when Blest Gana wrote Aritmética en el amor, the novel that catapulted him to national prominence. Regarding the novel's award, the jury, made up of Lastarria and Miguel Luis Amunátegui, highly valued its cuadros locales [local features] whose morality placed it far ahead of the other novel under consideration, Judith (by an anonymous author).

Within this framework, it is significant to note the similarity in the terms used by the awarding jury and those used by Blest Gana in his speech upon the occasion of his incorporation into the Universidad de Chile. The jury wrote that, unlike his competitor, the author of La aritmética en el amor "has highlighted the ugliness of selfishness and the beauty of virtue, making available for readers a certain number of characters who symbolise either degradation or moral elevation." Also, regarding the national character of the novel, the jury was of the opinion that "Aritmética en el amor is animated by a large number of national cuadro de costumbres, full of colour and truthfulness" (Silva Castro, "Blest Gana y su novela” 34,35). The awarding judges found two apparently uncontested values in the novel: a cuadro costumbrista and moral edification.

Fortunato Esperanzano, the symbol-laden name of the protagonist of La aritmética en el amor, belongs to the world inhabited by types such as Martín Rivas (eponym of Blest Gana's famous novel), Casimiro (El jefe de la familia) [Family Patriarch], and Pablo Reina (Un drama en el campo). These characters are all poor or impoverished, linked geographically to the interior of the provinces - the countryside, or the hacienda - but settled or formed in the city, with a certain nobility of spirit and economic perspective. They are shaped by a distinctive social characteristic that is succinctly described in a recurrent phrase in the Blestganian narrative: "ese joven no era ni huaso ni vulgar" [that young man was neither a huaso (cowboy type) nor a vulgar man] (Blest Gana, El ideal de un calavera 75). Not to be a huaso - or not to be an "unhappy huaso" whose destiny, as El ideal de un calavera attests, is to be exploited by landlords - and not to be "vulgar," which means having received formal instruction or an overall education (standing for symbolic capital), seem to be indispensable requirements for the laborious and ascetic ethics of the "good citizen" that this type of narrative promotes.

Regarding the speech that Blest Gana delivered in 1861 when he joined the Universidad de Chile, the novelist displayed organically the guiding ideas governing his literary conception. It should be remembered, however, that those ideas had been discussed in the Chilean literary scene for at least a decade, and that one of his brothers, Joaquín, had used them previously in a variety of articles published in the press. ${ }^{6}$

5 These movements are inscribed in the intellectual space opened by the Sociedad Literaria of Santiago in 1842, chaired by Lastarria himself. In fact, in his Recuerdos literarios, the author of "El mendigo" [the Beggar] notably conceives of the Círculo of 1859 as a continuity of the Sociedad of 1842 ("El mendigo" is one of the first short stories in Chilean literature and is analysed later in this essay).

6 In four essays published in La Revista de Santiago between 1848 and 1849, Joaquín Blest Gana described with surprising lucidity the obstacles that every writer had to overcome to manage the production of a national literature. Two of these works were dedicated to the novel ("Walter Scott" and "Tendencias del romance contemporáneo" [Tendencies in Contemporary Romance), one to poetry ("Consideraciones generales sobre la poesía chilena” [General Considerations of Chilean Poetry], and a final one, which encompassed both genres, "Causas de la poca originalidad de la literatura chilena” [Causes for Scarce Originality in Chilean Literature]. For this particular essay, Joaquín Blest Gana approached and revisited romanticism from the perspective of the past. For further information, see Subercaseaux (1981), and Pas (2014), especially chapter III, "Ensayos, crítica: Chile" [Essays, Critiques: Chile], where these and other texts of the time have been reinstated. 
Blest Gana began by pointing out the prevalent sentimental character conveyed in the genre of poetry up to that point, a reverberation produced by an affected romanticism, one that was incisively criticised by the Amunátegui brothers and also present in the reflections of his brother Joaquín as they appeared in $L a$ Revista de Santiago a decade earlier. By contrast, Blest Gana underlined the advantages that the genre of the novel provided, since it allowed a wider reach to a less initiated audience: "Todas las clases sociales, todos los gustos [...] encontrarán en la novela un grato solaz, un descanso a las diarias tareas [...]” [All social classes, all tastes [...] will find in the novel a pleasant solace, a break from daily tasks] (Silva Castro, "Blest Gana y su novela" 43). He added:

\begin{abstract}
Para llenar las condiciones que anunciamos, sin disputa la novela de costumbres es la más adecuada. Por la pintura de cuadros sociales llamará la atención de todos los lectores; por sus observaciones y la filosofía de su estudio, adquirirá las simpatías de los pensadores, y por las combinaciones infinitas que caben en su extenso cuadro despertará el interés de los numerosos amigos del movimiento y de la intriga [...]; el escritor puede combatir los vicios de su época con el vivo colorido que resalta en el diseño de cuadros de actualidad y encomiar, por medio de otros de igual naturaleza, las virtudes cuya imagen importa siempre presentar al lector en contraposición de las flaquezas humanas. (Silva Castro, "Blest Gana y su novela” 44)
\end{abstract}

[To fulfil the conditions that we have announced, without any dispute the novel of costumbres is the most appropriate one. By its pintura de cuadros it will attract the attention of all readers; by its observations and the philosophy of its study, it will obtain the sympathies of thinkers, and by the infinite combinations that fit within its extensive cuadro it will awaken the interest of the numerous adepts of movement and intrigue [...]; writers can combat the vices of their times with vivid colours that will stand out in the design of contemporary cuadros and praise, through other cuadros of the same nature, the virtues whose image is always important to present to the reader in contrast to human frailties.]

In this fragment lies the core of the Blestganian project, as critics have widely noted. The prescribed costumbrismo results from a need to provide readers with shared scenes and motifs that would serve the purposes of awakening interest in reading. Likewise, the notion of "contemporary cuadros" summons various audiences: the cultured ones - the "thinkers" in the novelist's terms - and the popular ones or, in an interested representation of the times, the feminine ones. These correspond to "the numerous adepts (males and females) of movement and intrigue" (i.e. readers of folletines). Toward the end of his speech, Blest Gana consistently and coherently raised again the obstacles that would be imposed on this project, ones which he had already pointed out in his own contribution to La Semana: the preponderance of foreign novels and, more precisely, the plots from folletines that stigmatised the social function inherent in the literature for a broad, educated sector. Blest Gana's narrative project owes its beginnings, therefore, directly to the much vilified relationship between novel and folletin and to the link between the novel's material and the daily space of the printed newspaper. This is evident despite the author's express attempt to overcome "bad" readings and thereby design a space for a local literary market that was opposed to foreign folletines.

\title{
3 Within the Space of the Folletín
}

Toward the beginning of the twentieth century, le feuilleton occupied, in the European press, a precise newspaper space - the rez-de-chausée [foot of the page] - which characteristically published varieties, miscellaneous items, fashion chronicles, policiales [detective stories], etc. As the bourgeois public made greater demands for entertainment or recreation and, concurrently, as the press became modernised, the folletin began to take on an increasingly more defined format. It formed ties with the dramatic genre and narrations of costumbres but differed from those in its typical structure à suspense.

Émile de Girardin, in his Parisian newspaper La Presse, was the founder of the genre of the romanfeuilleton, that is to say, of a novel published in instalments in the bottom part of a newspaper. In most cases - even in the most resoundingly successful case, such as that of Les Mystères de Paris - the narratives were characterised by ternary structures where suspense and the depiction of bloody events predominated 
to stimulate the readers' interest. This was configured with archetypal characters (hero, villain, vigilante) and published with deliberate cuts to induce expectation about the stories' resolution. ${ }^{7}$

From then onwards, the literary folletin imposed itself on the European print market and subsequently moved into the Latin American press, whose newspapers' bottom pages began to be covered with the names of mostly French authors from the famous serialised novels in the early and mid-1840s. ${ }^{8}$ This typographic space was ambiguous, if not hybrid, and it was where fictionalised accounts and news coexisted - to use contemporary terms. Indicatively, a verista prose of informative discourse sat alongside a literary discourse in a broad sense. Recently, Marie-Eve Thérenty (2013) has reported about these crossovers in the French press. Marlyse Meyer (1996) says of this "co-habitation" that the folletin was the space through which fiction filtered, and in many cases, it was the filter for the political or pedagogical word.

It should not be surprising, then, that in his first narrative period, from 1853 to 1863, Blest Gana published most of his work in this format. ${ }^{9}$ There is, of course, one important point of distinction: the format consecrated by Alexandre Dumas and Eugène Sue possessed qualities that went beyond its serial attributes. Not all narratives or novels published in instalments were necessarily framed within the structures used by Dumas and Sue, since they were either previously written or did not contemplate the conditions or the rhythms of the roman-feuilleton. In this sense, most of the foreign stories that were published in the 20 years that passed between the meetings of the Sociedad Literaria of 1842 and Blest Gana's speech do not correspond to the strict structure of the folletin but to the relato seriado [serial account], which had begun to operate in France in 1829 in the Revue de Paris. With that said, a careful reading of Blest Gana's novels published in the press could demonstrate the use of some of the tools - notably suspense - typical of the narrations of a folletin. For example, one can think of the short novel Un drama en el campo, which ran in two instalments in La Semana, where the end of the first instalment underscores an attempt to keep the readers' interest. The dialogue between two brothers, in love with the same woman, is suspended by a challenge:

[...] En verdad, no sé por qué nacimos hermanos, cuando la suerte nos destinaba para enemigos. Tú amas a Paulina, me dices; pues bien, yo seré tan franco como tú: yo también la amo i he resuelto que será mía, ¿entiendes?, lo he resuelto.

I diciendo esto me dejó solo, sin esperar mi respuesta.

ALBERTO BLEST GANA

(Continuará.) (La Semana, no. 8, 9th July 1859).

[In truth, I don't know why we were born brothers, when we were fated to become enemies. You love Paulina, you tell me; well then, I'll be as frank as you: I love her too and I've decided that she will be mine, do you understand? I've solved it.

And saying this he left me alone, without waiting for my answer.

(To be continued).]

7 In truth, the first to produce a story with these characteristics was Honoré de Balzac, who began to publish in Girardin's newspaper La vieille fille in October 1836, although not in its main body but in the Variétés section. Cfr. La Presse, no. $103,1836$. About the folletín, among others, see Meyer (1996); Bory (1962); Queffélec-Dumasy (1989).

8 To the trio represented by Balzac, Dumas and Sue, we should add Eugene Scribe, Victor Hugo, Samuel Henri-Berthoud, Gustave Beaumont, Casimir Delavigne, George Sand, Frédéric Soulié, Paul Féval, but also include Ann Radcliffe, Samuel Richardson, Jean-Jacques Rousseau, Byron, among the most recurrent names. Certainly, as can be inferred from the names cited here, not all of them are strictly contemporary nor did they all publish serialised texts in a strict sense.

9 Besides his articles on costumbres, Blest Gana published Una escena social in the newspaper El Museo (1853); Engaños y desengaños, and Los desposados in La Revista de Santiago (1855); El jefe de la familia (theatre play) in El Correo Literario (1858); El primer amor, La fascinación, and El pago de las deudas in the Revista del Pacífico (the first two in 1858 and the latter one in 1861); Un drama en el campo in La Semana (1859); and Martín Rivas, El ideal de un calavera, La venganza, and Mariluán in La Voz de Chile (between 1862 and 1863). 
Within the framework of competition with the folletin, Blest Gana's literary production had to operate simultaneously on two levels: on the one hand, inscribed within the space of the folletin, the author's narrations competed necessarily with foreign publications then in vogue (for instance, when Martin Rivas was published in the main body of $\mathrm{La}$ Voz de Chile, the newspaper had been publishing folletines by Carolina Coronado, Schiller, José Castro y Serrano, Fernán Caballero); on the other hand, that inscription allowed him (as well as forced him) to gain the attention of readers already trained in this type of literature. But Blest Gana sought to reorient their choices. For this purpose, appealing to costumbrismo and, particularly, to the epistolary genre became his main resources for narrative construction and seduction.

\section{A Passion for Orthography: A Pedagogy of Reading}

As has been widely observed, readings of Balzac and Stendhal were instrumental in shaping the Blestganian narrative. The realism of descriptions, a vein of costumbrismo, and the thematisation of sentimental development all carefully conformed to Stendhal's theory of love. Hence, these aspects all unavoidably coexist in the Chilean author's narrative project (Goić 33-49). But perhaps Blest Gana's most deployed element is the epistolary genre, begun by Rousseau with La Nouvelle Héloïse (1761) and continued with novels by Richardson in England. Absolutely all Blest Gana novels include an epistolary exchange as a narrative modality. Among the genres of social representation of reading, letters are coded representations of writing. In the tracing of a letter - in grammar and orthography - customs and social hierarchies are made visible.

Epistolary communication was also one of the modes of intimate relationship that could best circumvent the period's rigid limits of public morality, especially in the case of the female universe. Domingo F. Sarmiento, who understood (as Blest Gana would later understand himself) the productivity of reading promoted by the folletines, appealed early on to this resource in El Progreso - not coincidentally, within the same space of the folletin - with a series of feigned (or rather, fictionalised) letters between two female friends. One from Santiago and the other from Valparaíso, the two women narrated events in the capital with touches of humour and fine irony and added costumbrista brushstrokes..$^{10}$ It should be noted, moreover, that in the history of the press - or, if one would prefer, to be in line with Jürgen Habermas, in the history of a new notion of Öffentlichkeit - epistolary correspondence played a leading role in cementing a new public subjectivity. Actually, the press has been thought of as a confluence of conversational grammar (causerie) and the epistolary genre, which highlights the fact that newspapers contain an oral dimension. ${ }^{11}$ Until well into the nineteenth century, there was a pervasive presence of manuals, treatises, and rhetorical texts on epistolary use, a whole propaedeutic oriented towards grammar eloquence in epistolary correspondence, whose surrounding framework, incidentally, was the illustrated rhetorical texts that go from Ignacio Luzán to Hermosilla, passing through the famous and peremptory lessons of the Scotsman Hugh Blair.

Epistles were also a way to represent social conflict, as can be seen early on in "El mendigo," by Lastarria, published in El Crepúsculo (1843). This work, which has attracted attention for being one of the first stories of Chilean narrative, is of special interest here. It contains an allegory which has not been sufficiently explored by critics and that directs us again to the relationship between epistolary exchange, public morals and literary interests and activities. "El Mendigo" is the story of an old soldier of the nation, Álvaro de Aguirre, “a character very different from the character he represented.” Despite having fought in

10 The (feigned) letters between Rosa and Emilia were published between 16 November 1842 and 2 January 1843 in El Progreso, founded by the brothers Manuel and Rafael Vial Formas. Sarmiento was a contributor to El Progreso from its beginnings. 11 See José-Luis Díaz (695-715) and his reflections on private eloquence and rhetoric in the press, part of his contribution to the monumental La civilisation du journal.

12 Subercaseaux has reflected on this question in his book on Lastarria, stipulating that "El Mendigo" is a novelistic essay with which its author intended to put his literary conceptions into practice. 
Chillán and Rancagua under the command of Carrera, first, and O'Higgins later - two Chilean founding fathers - he spent his days as a beggar on the streets of Santiago. As always, beneath the rags of a beggar hides the identity of the nation. Along with the figure of the outlaw, noted by Subercaseaux (63), the story thematises the passage from Spanish to republican government and its lasting consequences, which have not yet been resolved in the present of Lastarria's narrative. The theme is romantically assembled into a love story where historical events and contingences (such as the wars of Independence, political betrayals, and colonial impositions) rather than class conflict made a happy ending impossible. In this frame, it is symptomatic that what defines the fate of that love story - and that of the main character - is the impossibility of written communication. When Aguirre returns from Lima to La Serena, Lucía, his young love, has been entrusted to the care of a Spaniard, Gumesindo Salias.

After much speculation and several failed attempts to get closer to his beloved, Aguirre manages to pass himself off as a carpenter in order to infiltrate the house and deliver a letter to his beloved. The episode is narrated in the first person by the protagonist:

Luego trajeron a D. Gumesindo una gran taza de chocolate, él se desvió un poco de la puerta del oratorio para tomársela al sol y aprovechando yo aquel momento, saco mi carta, y se la tiro a Lucía; ella la recogió y sonriéndose la besó. Vuelvo a aserrar otra tabla y Lucía acercándose a la puerta me dice en una voz suave y dulce: “Álvaro, ¡yo no sé leer!” (El Crepúsculo, no. 7,281$)$

[After they brought Don Gumesindo a large cup of chocolate, he moved a little away from the door of the oratory to drink it under the sun, and taking advantage of that moment, I took out my letter and threw it to Lucia; she picked it up and, smiling, kissed it. I returned to sawing another board and Lucía, approaching the door, told me in a soft and sweet voice: “Álvaro, I don’t know how to read!.”]

Manuel Vicuña recalls the resentment that parents felt, during colonial times, towards the ability to write because they feared that their daughters might use it to secretly exchange letters with their lovers (81). It is significant, then, that Lucía, finally, becomes a pledge of Spain and Aguirre loses his mind due to a "fatal passion" - and not because of the war. Love, passion, and lecto-escritura [literacy] combine with each other to form the core of the melodrama, just as they do in the Blestganian novels.

But the inheritance of colonial cloistering, an impediment to achieving a language of love in Lastarria's story, becomes for Blest Gana one of the greatest resources for a love story to represent the social and cultural codes of the times. The love language that pervades the correspondence among characters in Blest Gana's novels displays a confrontation between the grammar of passionate sensitivity and the grammar of civil institutions. An evaluation of the social conditions of the protagonists is made via the epistolary mode of communication. When Abelardo Manríquez, the hero of El ideal de un calavera, wrote his first love letter to Inés Arboleda - daughter of Don Calixto, owner of a farm neighbouring that of Manríquez - the narrator comments that Inés had trouble answering the letter:

Mas era necesario hacerlo por escrito, y de aquí surgía una poderosa dificultad, que el autor se ve precisado a enunciar francamente, a fin de no quitar a su historia el sabor de la realidad, tan importante en los estudios de costumbres.

Inés se arredraba ante las tiránicas exigencias de la ortografía y de la redacción.

Como las personas de su sexo en general, la hermosa joven temía más descubrir su falta de cultura en una carta mal escrita, que el compromiso que esa misma carta podría originar a su buena reputación. Muchos amantes han maldecido el recato de una querida, sin figurarse que sus verdaderos enemigos han sido las reglas de ortografía. (Blest Gana, El ideal de un calavera 131).

[But it was necessary to do it in writing, and from this emerged a great difficulty, which the author is forced to state frankly, in order not to remove from his story the flavour of reality, which is so important in the studies of customs.

It was a daunting task for Inés to face up to the tyrannical demands of orthography and writing.

Like people of her sex in general, the beautiful young woman was more afraid of revealing her lack of culture in a poorly written letter than of how compromising that letter might have proved to be for her good reputation. Many lovers have cursed the modesty of a mistress, without realising that their real enemies have been the rules of orthography.] 
While revealing the effects of conservative pedagogical programmes with respect to the education of women - overcome by individual reading, such as that of doña Francisca in Martín Rivas - the passage also demonstrates the ways in which social codes are transmitted through writing. But if the passage's presentation seems to be generic - "las personas de su sexo en general" [people of her sex in general], the narration says (131) - the same novel is responsible for imprinting class distinction. After Manríquez leaves the countryside - and Inés's impossible love - to return to Santiago, he begins an affair with Candelaria, a woman from a low social sphere, with whom he tries to forget about Inés. After Manríquez receives a declaration of love from Candelaria, one of his calavera friends, privy to Candelaria's letter, comments, "Hay más pasión que ortografía" [I see more passion than orthography] (El ideal de un calavera 253). A failure in orthography, thus, predictably leads to the impossibility of Candelaria and Abelardo's love. After all, although Manríquez does not belong to the monied aristocracy, he nonetheless comes from a bourgeois family like Martín Rivas and Fortunato Esperanzano. ${ }^{13}$

Through the reading of love stories, Blest Gana intends to offer a model of subjectivity that radiates the values of a public and bourgeois conscience. In this sense, domestic spaces and intimate scenes represent the basis of family and private dramas which constitute the political fabric of national sociability. It is in these intimate spheres that the novelist must find the sources from which he will extract the matter of representation and social modelling. In this fashion, the novel is presented as a conduit for transforming habits that are rooted outside the legal and institutional order. It is not by chance that, in most of his novels, the material impossibility of love - due mostly to traditional social conventions - is resolved by the action of escaping. With respect to the aforementioned short novel Un drama en el campo, it is not coincidental that it begins with a letter from Emilio Reina to his cousin Pablo Reina. The latter has escaped with his beloved Paulina, who must then assume the (social and material) costs of such action: "El paso que has dado - le escribe el padre al enterarse de su resolución - sólo a ti te perjudica, pues desde ahora quedas privada de toda herencia" [The step you have taken - her father writes upon learning of her resolution - only harms you, because from now on you are deprived of all inheritance]. ${ }^{14}$ Just as orthography can register social and cultural difference, the love story puts on stage the material structure that governs, in a certain anachronistic manner, the social exchanges of the present.

The links regarding family legitimacy, found in the Civil Code of 1855 , such as the regulation of kinship assets and parental responsibility in a family nucleus, are issues that are not fortuitously linked with subjective love experiences in the narrative costumbrismo of Blest Gana. Towards the end of the 1850s, the heterogeneous material of El Correo Literario provided a platform for liberal and traditional expression in the form of cartoons, satirical discourse, weekly chronicles, and the publication of poems, folletines and relatos seriados. In El Correo Literario, Alberto Blest Gana published El jefe de la familia, a drama that was not performed at the time and which centred on an intrigue between material interest and the morality of costumbres. This narrative focus features clearly in the plots of his most famous novels. The story takes place in the house of Manuel and Prudencia Bustos, whose 17-year-old daughter Clara provokes a love dispute between Enrique (a "rogue," who makes the family believe that he owns a mine in Copiapó, in Northern Chile) and Casimiro, a poor suitor with noble aspirations. In one of the dialogues between the two young men, they anticipate Fortunato Esperanzano's perspective from La aritmética en el amor:

13 The introduction in the novel of La Nouvelle Héloïse is significant. When Blest Gana makes his hero explain the meaning of his ideal - the one that gives the novel its title - the author offers us a representation of the social efficacy of reading novels: "Una simpatía inexplicable arrastró mi predilección hacia Eloísa [...]. Desde entonces soy esclavo de esta idea, vivo para realizarla, le consagro mi alma, hago de ella el único grande objeto de mi vida: jese es mi ideal!” [An inexplicable sympathy dragged my predilection towards Eloísa [...]. Since then I have been a slave to this idea, I live to realise it, I consecrate my soul to it, I have made it the only great objective of my life: that is my ideal!] (Blest Gana, El ideal de un calavera 363).

14 La Semana, no. 9, p. 133. In the short novel Juan de Aria, the "law graduate" and therefore "his home's only hope," escapes with Julia, who lived in the possession of a military man. In La aritmética en el amor, the protagonist Fortunato Esperanzano elucidates an escape with Margarita Mantoverde, which finally fails due to a typical melodramatic entanglement. 
Enrique: Pues bien, si practicas esas bellas ideas, conseguirás un día casarte por amor, tendrás una mujer llena de ilusiones y ambos bajaréis tomados de la mano del séptimo cielo de esa felicidad, a comer puchero y el charquicán servido por alguna gorda huasa de Maipo.

Casimiro: Y por qué no he de alcanzar la fortuna.

$[\ldots]$

Casimiro: No, con honradez y laboriosidad se puede alcanzar todo, y si al fin se logra la fortuna, icon qué orgullo se disfrutará de un bien tan noblemente adquirido! (El Correo Literario, no. 11, 131-32).

[Enrique: Well, if you adhere to those beautiful ideas, one day you will marry for love, you will have a wife full of illusions and both of you will come down hand in hand from the seventh heaven of that happiness, to eat stew and the charquicán served by some fat huasa from Maipo.

Casimiro: And why shouldn't I become rich?

$[\ldots]$

Casimiro: No, with honesty and diligence everything can be achieved, and if fortune is finally achieved, with what pride I will enjoy such a nobly acquired good!]

The relationship between money and morals, effort and pride - note that the model protagonist, Casimiro, does not give in to romantic love but takes on the industriousness that will give him material success, namely, sustenance and social prestige - will reappear both in Fortunato Esperanzano, whose name, as stated earlier, sums up a whole symbolic structure, and in the eponymous protagonist of Martín Rivas. In this novel, orthography will also play a decisive role in social representation. The lovers of the so-called medio pelo sector - Edelmira, Adelaida - lack a central element that the novel's moralising perspective will not fail to underline: a formal education, or rather, good grammar. The passionate letters that Edelmira sends to Rivas are redacted ("purged") by the narrator, as if their content could apparently be detached from its sender. As readers of Blest Gana already know, however, a formal slip accompanies and anticipates sentimental frustration.

\section{Martín Rivas, or the Institutionalisation of Literature}

There are at least two very generalised interpretative readings of Blest Gana's most famous novel: traditional criticism reads it following the guidelines of the costumbrista story (Silva Castro, 1941), while others see in the novel, a representation of the economics that govern the behaviour and alliances of the capitalist bourgeoisie (Concha, 1972; 1985), or even a social representation of civic virtues (Goić, 1968). Doris Sommer (1991), closely following Fredric Jameson, has read the marriage alliance between Leonor and Martín as the symbolic resolution of real social conflict. For Sommer, the novel represents a hybrid between erotica and politics, which the term "romance" encourages in its semantic ambiguity. In short, Sommer's interpretation is not far from what Jaime Concha first argued, but it emphasises its melodramatic side by extolling the relationships between love and politics, morals and money. Susana Zanetti (2002), for her part, prefers to do a reading of the author's moderate liberalism, which is visible in the representation of reading scenes. This is especially evident in the figure of doña Francisca, but also in Edelmira who, thanks to her frequent use of romantic novels and folletines, distinguishes herself from her social sector $-\mathrm{a}$ fact which promotes the legalisation of moral effects offered by literacy and the development of formal education programmes.

For his part, Juan Poblete (2003) has focused on the new discursive genres promoted by female culture in the Chilean elite's spaces of sociability. For Poblete, Blest Gana knew how to incorporate the interests of a broad public in order to channel them into a reformulated reading of the social habits of the time. Hence, this type of education of the feminine reading sensibility - the one most inclined to the romantic sentimentality of the folletines - is in accord with the pedagogical programmes with which the elites sought to 
educate the people. Therefore, the modelling reading system also implies the postulation of a hegemonised and unique sphere of what is public, recognisable in the values of the urban elite. The educational project, according to Poblete, aimed to instil social respect for property: "to make the popular legal citizen understand that the property enjoyed by owners was legitimate and that, in its turn, it was reflected in the propriety with which they appropriately used the language" (181).

The question of citizenship, ownership and propriety of language, as we saw with regard to the use of orthography, is central to Blest Gana's narrative symbology. From this prism, the editorial project of $L a$ Voz de Chile, a newspaper founded by the liberal Manuel A. Matta, to whom Blest Gana would later dedicate his novel, cannot be overlooked. The reformism encouraged in the newspaper's pages coincides with an idealisation of virtues displayed by the novel's protagonist. At the same time, its sections on "National Literature" motivate the authorial productions by the literate elite. ${ }^{15}$

Such an imprint perhaps explains Blest Gana's inclination to situate the story of Martín Rivas in the year of a revolt originating with the Sociedad de la Igualdad. His choice to narrate distant events from 1850, as opposed to those that took place in the civil war of 1859 , allows the author to adjust a representation that, avoiding references to more recent events, nevertheless activates a reformism devoid of the danger and violence conjured by the same editorial lines of La Voz de Chile. ${ }^{16}$ What is significant in the novel, thus, is not so much the different fate afforded to Martín Rivas and his Byronian friend Rafael San Luis in their participation in the Motin de Urriola, but the reasons that led one and the other to participate in the Urriola uprising. Surely, the active militant in this rebellion is not Rivas but his friend, Rafael San Luis - who also incites and convinces the former to participate. When the uprising is finally crushed in the capital and Martin is taken prisoner, his beloved Leonor, the daughter of wealthy Dámaso Encina, intervenes to seek her father's influence over the government to obtain the protagonist's release. The following is a key passage from their dialogue:

Usted sabe, papá, que Martín es un joven de esperanza: usted mismo lo ha dicho muchas veces; es también de muy buena familia; no le falta, por consiguiente, más que ser rico, y estoy segura de que con las aptitudes que usted le reconoce, nunca será pobre [...] Ahora que él se encuentra gravemente comprometido y que por desesperación tal vez ha tomado parte en la revolución, debemos nosotros pagarle con servicios los muchos que le debemos. (Blest Gana, Martín Rivas 347)

[You know, dad, that Martín is a young man full of hope: you yourself have said it many times; he also comes from a very good family; the only thing he is missing is being rich, and I am sure that with the aptitudes that you recognise in him, he will never be poor [...] Now that he is seriously compromised and perhaps out of desperation took part in the revolution, we must repay him for the many services that we owe him.]

15 The section "National Literature," which generally occupied the upper part of the newspaper's first two or three pages, among local and foreign folletines, published poems by Guillermo Blest Gana (another of the author's brothers) (No. 24, 8 April 1862); articles of costumbres by Daniel Barros Grez (No. 18, 1 April 1862); poetry essays, such as those by the Amunátegui brothers on Andrés Bello (No. 86, 21 June 1862). Among the latter, it is worth mentioning, among others, Dicha y suerte, cuadro de costumbres populares by Fernán Caballero (No. 18, 1 April 1862); Guillermo Tell by Schiller, translated by Manuel A. Matta himself (No. 21, 5 April 1862); Cuerdos y locos by José de Castro y Serrano (No. 39, 28 April 1862); Un cementerio a la orilla del mar by Charles Dickens (No. 223, 4 December 1862). Among the local folletines, Alberto Blest Gana's have a prominent space, such as La venganza (tradición limeña) (No. 15, 28 March 1862), Martín Rivas, (whose first instalment begins at No. 47, 7 May 1862), Mariluán (crónica contemporánea) (No. 186, 30 October 1862), and El ideal de un calavera (No. 438, 12 August 1863). It should be noted that in issue No. 243 of 25 December 1862; that is, after Martín Rivas and Mariluán, José Mármol's Amalia begun its publication in the newspaper.

16 In its first issue, the newspaper's editorial described its objectives: "Lovers of the Republic, sincere supporters of Democracy, we see the security, greatness and well-being of our society in planting any type of seeds that will foster the consolidation of the bases of our Republic, turning away each day from violence and corruption - which are unsettling for any type of social order - and in a more rational organisation, more appropriate to our way of conceiving Democracy, opening a free and wide field to the full exercise of freedom and justice - levellers of inequalities, balancers of all collected forces. For this reason, our main purpose will be to defend, consolidate and extend self-government for individuals and for peoples, since we are convinced that this is the best and only means to remove the danger and harm inflicted sometimes by the abuses of both those who govern and are governed from the frequent, but necessary changes in the Republic, as well as from the continuous but fruitful struggles of Democracy. This is our pledge” (La Voz de Chile, No 1, 12 March 1862, p. 1). 
Leonor's careful argument, the values and ideas represented in it - Martín is not "rich" but he will neither be "poor" - and her casual comment about his illegitimate participation in the events of the insurrection Martín, really, was driven more by desperation (from love) than by any political will - masterfully summarise the moderate liberal project of the Blestganian narrative.

More relevant yet, in the diligence and study of such an exemplary protagonist, we find a double and contradictory representation that is typical of Blestganian literature. First, we see a secondary talent affirmed by Blest Gana in his article "De los trabajos literarios en Chile:" despite the imbalance between the European and the local literary markets, Latin American writers must persist to capture the interest of a new public; by doing this, they can pave the way for the formation of a national literature. Second, an institutional and moralising destiny is suggested by the consecration of Martín Rivas's lineage - which in Spanish I have coined as martinrrivista - in relationship to characters such as Juan de Aria, Fernando Reinoso, Camilo Ventour, or Rafael San Luis himself. This finishes by stifling the imaginary possibilities of fiction under the modelling and utilitarian impulse of a liberal State, restricting them to a canon that has been made to be appropriate.

Undoubtedly, in these other novels, other modes of resolution and representation strive to establish themselves in the poetic imaginary of the author, which is like saying - following the logic interposed by the object of "public writing" - the imaginary or poetic horizon of that time in Chile. Juan de Aria, "law graduate," and "his home's only hope," battles between his studies of the Novisima Recopilación and his romantic inclinations, and this ultimately leads him to flee with his lover Julia (her death points to a martinrrivista morality that is not fully developed) (Cfr. Juan de Aria). Fernando Reinoso, the Werther from El primer amor, is the fictional character that best represents incipient literary inclinations. He is a poet with limited resources who manages to sell 100 copies of his poetry to pay off a debt that afflicts him and thus comes to realise that "poetry for those of us is a luxury" (Cfr. El primer amor). Camilo Ventour, the most exquisite figuration of an artist in all of Blest Gana's novels - precisely perhaps because the story is set in Paris - has established himself as an opera musician with his work La fascinación (note, incidentally, a modern literary self-reference in Blest Gana), thanks to the mediation of his friend, critic, and journalist. Here we must mention briefly the effective thematisation that Blest Gana exercises in this novel of the links between the press and the arts, that is, the ways in which the journalist or art critic's mediation - in the novel represented by Carlos, a kind of partenaire of his friend and protagonist Ventour - works empirically in the so-called "public opinion" (Cfr. La fascinación). Finally, the Byronian Rafael San Luis - who in this context could very well represent a figure like Francisco Bilbao - fights for the liberal ideas of the Sociedad de la Igualdad and dies in the fight against the Portalian army (Cfr. Martín Rivas).

A comparison between this series of protagonists - not coincidentally, almost all of them belong to novels written during the novelist's formative period-and the martinrrivista saga (Rivas, Esperanzano, and Manríquez) shows the path travelled by the author and how he adapted to the formal requirements promoted by the press (whose speculations and aesthetic disputes did nothing but bring together, according to their own interests, other disputes and speculations, paths that had already been trod by European critics and the press). Finally, during the early period of literary modernisation, Alberto Blest Gana became the best novelist in Chile, and even the best - if not the only - novelist in South America; he knew how to make operational a traditional idea of literary fiction, which some European authors at the time, such as Flaubert and Mallarmé, had begun to wish to transform and, even more rigorously, to demolish.

Funding information: Author states no funding involved.

Author contribution: I, Hernán Pas, wrote "From the Newspaper Serial to the Novel (1853-1863)" for a special volume titled Alberto Blest Gana at 100 to be published by Open Cultural Studies. I have accepted responsibility for the entire content of this manuscript and approved its submission.

Conflict of interest: Author states no conflict of interest. 


\section{Work Cited}

Blest Gana, Alberto. Un drama en el campo [A Drama in the Countryside], in La Semana, no. 8 (9th July), 1862, pp. 116-120 and no. 9 (16th July), pp. 131-135.

Blest Gana, Alberto. Una escena social [A Social Scene] 1853, La fascinación [The Fascination] 1858, La Aritmética en el amor [Arithmetic in Love] 1860. Zig-Zag, n.d.

Blest Gana, Alberto. El ideal de un calavera [The Ideal of a Rogue]. 1863. Andrés Bello, 1999.

Blest Gana, Alberto. El jefe de la familia [A Family Patriarch], edited by Raúl Silva Castro, Zig-Zag, 1956.

Blest Gana, Alberto. Juan de Aria, in El Aguinaldo de El Ferrocarril, 1858.

Blest Gana, Alberto. Martín Rivas [1862]. Prologue by Jaime Concha, Biblioteca Ayacucho, 1985.

Blest Gana, Alberto. El pago de las deudas [Payment of Debts]. 1861. Librería de Ch. Bouret, 1884.

Blest Gana, Alberto. El primer amor [First Love]. 1858. Zig-Zag, 1949.

Bory, Jean-Louis. Eugene Sue. Dandy mais socialiste [Eugene Sue. A Dandy but a Socialist]. Memoire du Livre, 1962.

Concha, Jaime. "Martín Rivas o la formación del burgués" [Martín Rivas or the Making of a Bourgeois]. Revista Chilena de Literatura, no. 5-6, 1972, pp. 9-36.

Díaz, José-Luis. “Avatars journalistiques de l'éloquence privée” [Journalistic Avatars of Private Eloquence]. La civilisation du journal. Histoire culturelle et littéraire de la presse française au XIXe siècle, edited by Dominique Kalifa, et al., Nouveau Monde éditions, 2011, pp. 695-715.

Fernández Larraín, Sergio. Epistolario Alberto Blest Gana, 1856-1903 [Alberto Blest Gana’s Epistolary, 1856-1903]. Editorial Universitaria, 1991.

Goić, Cedomil. La novela chilena [The Chilean Novel]. Universitaria, 1968.

Lastarria, José Victorino. Recuerdos literarios [Literary Memoirs]. 2nd ed. Librería de M. Servat, 1885.

Meyer, Marlyse M. Folhetim. Uma história [Feuilleton. A History]. Companhia das Letras, 1996.

Pas, Hernán, editor. El romanticismo en la prensa periódica rioplatense y chilena. Ensayos, críticas, polémicas (1828-1864) [Romanticism in the Río de la Plata and the Chilean Periodic Press. Essays, Critiques, Polemics (1828-1864)]. U Nacional de La Plata, Biblioteca Orbis Tertius/7, 2014. E-book: http://bibliotecaorbistertius.fahce.unlp.edu.ar/07-pas-1.

Poblete, Juan. Literatura chilena del siglo XIX: entre públicos lectores y figuras autoriales [Chilean Literature of the Nineteenth Century: Among Reading Publics and Authorial Figures]. Editorial Cuarto Propio, 2003.

Queffélec-Dumasy, Lise. Le Roman-feuilleton français au XIXe siècle [The French Feuilleton Novel in the Nineteenth Century]. PUF (Que sais-je?), 1989.

Román-Lagunas, Jorge. "Bibliografía anotada de y sobre Alberto Blest Gana” [Annotated Bibliography of and about Alberto Blest Gana]. Revista Iberoamericana, vol. XLVI, no. 112-113, 1980, pp. 605-47.

Serrano, Sol. Universidad y Nación. Chile en el siglo XIX [University and Nation. Chile in the Nineteenth Century]. Editorial Universitaria, 1994.

Silva Castro, Raúl. "Blest Gana y su novela La aritmética en el amor" [Blest Gana and His Novel La aritmética en el amor]. Atenea. Revista trimestral de Ciencias, Letras y Artes, year XXXVII, vol. CXXXIX, no. 389, 1960, pp. 27-47.

Silva Castro, Raúl. Alberto Blest Gana (1830-1920). Estudio biográfico y crítico (obra premiada por la Universidad de Chile) [Alberto Blest Gana (1830-1920). Biographical and Critical Study (Recipient of an Award from the Universidad de Chile)]. Imprenta Universitaria, 1941.

Sommer, Doris. Foundational Fictions. The National Romances of Latin America. University of California Press, 1991.

Subercaseaux, Bernardo. Cultura y sociedad liberal en el siglo XIX (Lastarria, ideología y literatura) [Culture and a Liberal Society in the Nineteenth Century (Lastarria, Ideology and Literature)]. Aconcagua, 1981.

Thérenty, Marie-Ėve. "El folletín en los periódicos del siglo XIX: ¿hecho literario o fenómeno social?” [The Feuilleton in Nineteenth-Century Newspapers: Literary Fact or Social Phenomenon?]. La invención de la cultura mediática. Prensa, literatura y sociedad en Francia en el siglo XIX. Instituto de Investigaciones Doctor José María Luis Mora, 2013.

Vicuña, Manuel. La belle époque chilena: alta sociedad y mujeres de elite en el cambio de siglo [The Chilean Belle Époque: High Society and Elite Women at the Turn of the Century]. Editorial Sudamericana, 2001.

Zanetti, Susana. La dorada garra de la lectura. Lectoras y lectores de novela en América Latina [The Golden Claw of Reading. Readers of Novels in Latin America]. Beatriz Viterbo, 2002.

\section{Newspapers}

El Correo Literario. Santiago, 1858; 1864-1865; 1867.

El Crepúsculo. Santiago, 1843-1844.

La Gaceta del Comercio. Valparaíso, [1842-1845].*

El Museo. Santiago, 1853.

El Progreso. Santiago, [1842-1845].* 
La Revista del Pacífico. Valparaíso, 1858-1861.

La Revista de Santiago. Santiago, 1848-1849.

La Semana. Santiago, 1859-1860.

La Voz de Chile. Santiago, [1862-1864].*

*The square brackets indicate the time period of my research in these newspapers. Other dates, without brackets, show the years the newspapers existed. 